\title{
Sedimentary Facies Relationships and Depositional Environments of the Maastrichtian Enagi Formation, Northern Bida Basin, Nigeria
}

\author{
Ojo Olusola J. \\ Department of Geology, University of Ilorin, P.M.B. 1515 Ilorin, Nigeria \\ E-mail:solafoluk@yahoo.com \\ Akande Samuel O. \\ Department of Geology, University of Ilorin, P.M.B. 1515 Ilorin, Nigeria
}

Received: September 14, $2011 \quad$ Accepted: September 27, $2011 \quad$ Published: March 1, 2012

doi:10.5539/jgg.v4n1p136 URL: http://dx.doi.org/10.5539/jgg.v4n1p136

\begin{abstract}
The sedimentary facies of the Maastrichtian Enagi Formation exposed across the Agbona ridge at Share and Shonga areas was investigated for the first time to characterize their depositional facies and interpret the depositional environments. Well exposed vertical profiles of the sediments were studied along road cuts, erosional channels and cliff drops with special attention focused on their internal physical and biogenic attributes. The facies and facies associations in the lithostratigraphic units mapped include conglomerate, sandstone and claystone.

The conglomerate facies is moderately sorted; grain supported and mature, showing evidence of reworking and recycling. Association of this facies with herringbone cross stratified sandstone beds probably indicates tidal channel lag origin. The sandstone facies are commonly compositionally mature, bioturbated and contain clasts of reworked clays and clay drapes and these suggest high energy tidal channels and shoreface. The associated unidirectional cross bedded sandstones subfacies and kaolinitic claystones are interpreted as braided fluvial channels and floodplain deposits.

The gross sedimentation pattern and characteristics suggest predominance of trangressive shallow marine processes occasionally incised by fluvial channels. The clay deposit associated with the floodplains may offer economic resource potential in the area.
\end{abstract}

Keywords: Shonga, Bida basin, Shoreface, Channel lag, Paleoenvironment

\section{Introduction}

The Bida Basin is a linear NW - SE trending embayment and is oriented perpendicular to the main axis of the Benue Trough and the Niger Delta basin of Nigeria (Figure 1). To the east, it is contiguous or adjacent to the Anambra Basin and these basins were major depositional axes for transgressive and regressive sediments in the late Cretaceous times of Nigeria. To the northwest, it is adjacent to the Sokoto Basin. The basin is often geographically divided into northern and southern Bida Basins due to the wide variation of the facies across the Basin.

The geology of Bida Basin has received the attention of many workers in the last forty decades. Essentially, the works of Adeleye (1973, 1974), Braide (1992a) and Olaniyan \& Olobaniyi (1996) focused on the sedimentology and aspects of stratigraphy of the northern part of the basin. More attention has been on the southern Bida Basin, however, probably due to its seemingly mineral potential. Jan Du Chene et al. (1978), and Ojo (2010) reported on the palynomorphs assemblages and paleoenvironments and dated the shaly facies of the Patti Formation as Maastrichtian. The origin of the oolitic ironstones (Agbaja Formation) in the Bida basin had been widely discussed in several published works e.g. Adeleye (1973), Ladipo et al. (1994), and Abimbola et al. (1999). Some authors have also addressed some of the components of the petroleum potential of the Bida Basin as part of the on-going studies of the petroleum potential assessments of the Nigerian Inland basins (Idowu \& Enu, 1992; Braide, 1992b; Ojo, 1992; Obaje et al., 2004; Akande et al., 2005). 
The present work covers the traverse south of the Niger River (Share - Shonga areas, Figure 2). Even though, the rocks in this region basically are lateral equivalents of those in the northern parts, their distribution, geological developments and depositional history are worth studying and, indeed, the documentation will help to further understand the geology of the entire basin. It should be pointed out here that all the work on the northern Bida basin cited above are obviously restricted to areas north of river Niger and did not cover the present area where huge sediments are preserved. It is our thinking that precise location and accurate representation of the vertical and lateral variations of the sequences to further understand the paleogeography of the entire basin would be significant. Also, from our experience in the southern Bida Basin (Ojo \& Akande, 2006, 2009), the depositional model of Braide (1992b) which forecloses influence of marine processes in that basin needs to be re-examined.

\section{Geological Setting and Stratigraphy}

Consensus of opinion on the origin of the Bida Basin is that the upper Cretaceous sediments, which are essentially clastics deposited in rift basin associated with drifting apart of South America and Africa plates (King, 1950; Kennedy, 1965; Agyingi, 1991). Interpretation of Land sat images, borehole logs as well as geophysical data across the entire Bida Basin by Kogbe et al. (1981) suggest that the basin is bounded by a system of linear faults trending NW/SE. Gravity studies also confirm central positive anomalies flanked by negative anomalies as shown for the adjacent Benue Trough and typical of rift structures (Ojo \& Ajakaiye, 1989; Kogbe et al., 1983). Ojo (1984) and Udensi \& Osazuwa (2004) suggested an estimate of $4000 \mathrm{~m}$ as the maximum thickness of the sedimentary successions in the central axis based on gravity and magnetic surveys. Adeniyi (1985) through ground and aeromagnetic studies have also outlined the basin configuration. In a different model, the basin is thought to be associated with isostatic readjustments and gentle down warping or subsidence of the granitic basement complex as a result of the removal of mantle material which led to the emplacement of the Younger granite ring complexes during the Jurassic (Ojo \& Ajakaiye, 1989; Whiteman, 1982).

Braide (1992b) suggested a wrench fault tectonic model to explain the origin of the Bida Basin. By such a model, the Bida Basin could be considered as a graben resulting from the sinistral movements along the bounding Chain and Charcot fracture systems of the Benue Trough whereby the basin is developed at an angle to the major principal fault movements in which the horizontal movements translated to vertical movements leading to basement fragmentation and subsidence.

Four mappable stratigraphic horizons all of which are Campanian - Maastrichtian have been delineated and described in the northern Bida Basin (Adeleye \& Dessauvagie, 1972; Adeleye, 1974). The formations are Bida Sandstone, Sakpe Ironstone, Enagi Siltstone and Batati Ironstone. These correlate with Oldest Lokoja Formation, Patti Formation and Agbaja Ironstone Formation in the southern Bida Basin (Jones, 1955; Ojo \& Akande, 2003) (Figure 3). In the present study area, the studied sections correlate with Enagi Formation.

\section{Methods of Study}

Outcrops of the Maastrichtian sediments in the study area were measured and described with special attention paid to the internal features of the beds such as texture, mineralogy and physical and biogenic sedimentary structures. Vertical profiles of the sediments were studied along road cuts, erosional channels and cliff drops. The main access road used is Share - Shonga road (Figure 2). Lithostratigraphic columns (Figure 4) (in some cases composite) were constructed at various locations and photographs of significant features were taken for documentation and reference purpose. The paleoenvironments interpretation was attempted based on facies association, sedimentary structures, textures and petrography and using the concept of process - response model.

\section{Sedimentary Facies and Paleoenvironments.}

The sedimentological analysis of the sediments permitted the recognition of distinct facies and facies associations in the study area. Depositional facies that are quite distinct in term of architectural elements, lithofacies assemblage, microfacies, texture and sedimentary structures are tidal channel lag, tidal channel bars, shoreface, fluvial channel and floodplain. Among the lithofacies are conglomerate, sandstone and claystone and they outcropped mainly around Share and Shonga (Figure 2).

\subsection{Tidal Channel Lag Conglomerate Facies}

\subsubsection{Description}

This facies is composed of mainly grain supported conglomerate and the thickness varies from 0.3 to $1 \mathrm{~m}$ (Figure 4). It is important to note here that the grains are mainly well rounded quartz of average pebble size ranging from 2 to $8 \mathrm{~cm}$. Matrix is almost zero and in deed, they are moderately sorted and these provide indication of compositional maturity. In most cases, where they occur they are massive. At Share, the conglomerates are 
thinly bedded (less than $0.4 \mathrm{~m}$ ) and they fine upward into conglomeratic sandstones whereas at Shonga, the conglomerate is relatively thicker (Figure 5).

\subsubsection{Interpretation}

The conglomerate facies of the Enagi Formation shows features reflective tidal channel floor deposition of materials transported mainly via bottom traction. The moderate sorting and the mineralogical maturity (lack of feldspar and other labile rock fragments) suggest at least moderate reworking and recycling of materials, thus implying distal source. The presence of ophiomorpha burrows in this conglomerate may indicate a nearshore marine environment. The scenario envisaged here is that of a braided river evolving distally into tidal channels considering the association of this facies with hummocky and herringbone stratified sandstone in the sections (Prave et al. 1996; Amireh et al. 1994). The conglomerates are therefore interpreted as tidal channel lag deposits.

\section{2 Tidal / Shoreface Sandstone Facies}

\subsubsection{Description}

The sandstone facies varies texturally and in term of sedimentary structures from pebbly to fine grained and massive to stratified sandstone in the study area. The following subfacies are recognized; conglomeratic sandstone, cross stratified, medium to coarse grained sandstone, laminated fine grained sandstone. The conglomeratic sandstones are massive, burrowed and in places the thickness, attain an average of $5 \mathrm{~m}$. It is well represented in the upper parts of Share and Shonga ridge sections (Figure 4). In these sections, it grades upward into medium to coarse grained sandstones. The massive conglomeratic sandstones which are strongly bioturbated capped the fine and medium to coarse grained sandstones (Figure 6a) at Iyana. At Shonga, however, the conglomeratic sandstone subfacies are trough cross stratified. Here the trough cross stratified conglomeratic sandstone has an average thickness of $1.5 \mathrm{~m}$. Compositionally, it contains pebbly sized quartz grains that are moderately well sorted. Another notable feature of the conglomeratic sandstone is the occurrence of re worked clay pebbles (Figure 6b).

In many locations (Share, Iyana Share, and Shonga), the cross stratified, medium to coarse grained sandstone subfacies are exposed and shows mainly planar cross stratification which in some cases, are small scale and bidirectional (Figure 7. At Iyana, Share, they are overlain by the massive, bioturbated, conglomeratic sandstone and at many localities; they are interbedded with parallel laminated and massive fine grained sandstone. The cross bedded sandstones show bounding surfaces with clay drapes. The cross sets are small scale with low angles. The sands are typically reddish to pink in colour and compositionaly mature. Small clasts of reworked clays are also common (Figure 6b). In Share town (Agbona ridge west), some of the medium to coarse grained sandstone display herringbone and small scale hummocky cross stratification types. Ophiomorpha trace fossils are common in these sediments.

The fine grained sandstone subfacies is less common in the sections, however, where they occur particularly at Share and Shonga, they are commonly parallel laminated and in some cases, cross ripple laminations are preserved (Figure 7). At times the lamination is defined by alternation of kaolinitic clay laminae and red sands. Average thickness of this subfacies is $1 \mathrm{~m}$ in most localities. Sands size particles are dominantly quartz and hey also rich in muscovites. In some places the fine sands get clayey.

\subsubsection{Interpretation}

The characteristics of the sandstone facies in this area permit recognition of near shore high energy marine environments; tidal channels and shoreface environments. The herringbone cross stratified sandstone subfacies is interpreted as tidal channel facies. Klein (1970) and Amajor (1984) suggested that current direction reversals are associated with tidal processes. Clay drapes and worm burrows which are common in this subfacies have been reported as signatures of tidally influenced environments by Ladipo (1986) and Amireh \& Abed (1994).

The parallel stratified to massive sandstone subfacies characterized by hummocks in places, reworked clay pebbles and ophiomorpha burrows are interpreted as shoreface deposits (Walker, 1990; Taylor \& Lovell, 1991). Most probably, the horizontally laminated sands may be the product of sands been transported and reworked below the fair weather base and therefore forming within upper flow regime. Generally association of this subfacies with wavy laminations, convolute beddings, clay clasts and wave ripples suggest storm influenced high energy shoreface sub-environment (Castle, 2001; Dott \& Buorgeois, 1982).

\subsection{Braided Channel Sandstone Facies}

\subsubsection{Description}

This facies comprises of conglomeratic sandstone, medium to pebbly sandstone, and fine grained sandstone subfacies. The conglomeratic sandstone sub facies are well represented in the sections exposed at Agbona ridge 
at Share and Shonga (Figure 4). Generally, they are friable and contain pebbles of feldspars embedded in their clay and sand matrix. The thickness ranges from 0.5 to $2 \mathrm{~m}$ averaging $1 \mathrm{~m}$. In some cases, medium to coarse grained sandstones are cross stratified, massive and commonly pass upward into conglomeratic sandstone bed. They composed mainly of sands, minor silts and pebbles and their thickness range from 0.3 to $1 \mathrm{~m}$ and frequently interbedded with claystone and fine sands. Both planar and trough cross stratified sandstones are common (Figure 8a) but they are mainly unidirectional. The conglomeratic sandstones are massive in most places.

\subsubsection{Interpretation}

The sandstone facies comprising of the conglomeratic sandstone and medium to coarse grained sandstone sub facies is interpreted as braided fluvial deposits. The fluvial origin is supported by unidirectional paleocurrent pattern and absence of marine biogenic features (Ojo \& Akande, 2003; Rust \& Jones, 1987). The conglomeratic sandstone and medium - coarse grained sandstone in the study area is suggestive of development of low sinuosity channel bars arising from high discharge, fluvial incision and high discharge run offs (Allen, 1982; Selley, 1985; Blair, 1987). The conglomeratic sandstone lithofacies is thought to represent deep braided channel deposits and channel lag deposits.

\subsection{Claystone Facies}

\subsubsection{Descrption}

The claystone facies is well represented in Agbona and Shonga ridge sections (Figure $8 \mathrm{~b}$ ). The dirty white claystone beds are massive and show shrinkage crack features. At Agbona section, the claystone bed is about $2 \mathrm{~m}$ thick. It is kaolinitic and interbedded with cross stratified sandstone. The base of the claystone bed makes sharp contact with underlying cross bedded sandstone. It is important to note here that the kaolinitic nature of the clays have attracted the local artisanal miners who have over the years exploited it for pottery and medicinal purposes. Ojo et al. (2011) evaluated the industrial applicability and resource potential of the clays.

\subsubsection{Interpretation}

The predominance of clay minerals and clay size fraction in this facies indicate settling from suspension in a low energy environment probably the overbank or floodplain adjacent to the tidal channels (Miall, 1988, 1990).

\section{Conclusions}

The depositional model proposed for the Enagi Formation in the study area is that of largely trangressive shallow marine dominated process frequently incised by fluvial channels.

A shallow marine environment consisting mainly of shoreface and tidal channel facies as is suggested. The trangressive channel lag grades upward into tidal channel conditions.

Evidences of stream run offs such and periodic sub aerial exposure are common. The unidirectional cross bedded sandstones and the claystone represent fluvial channels and floodplains respectively.

\section{References}

Abimbola, A. F., Badejoko, T. A., Elueze, A. A., et al. (1999). The Agbaja Ironstone Formation, Nupe Basin, Nigeria. A product of replacement of a Kaolinite precursor. Global Journal of Pure and Applied Sciences, 5, 375-384.

Adeleye, D. R. \& Desauvagie, T. F. J. (1972). Stratigraphy of the Niger Embayment near Bida, Nigeria. In: T. F. J. Dessauvagie and A. J. Whiteman (eds). African Geology, University of Ibadan Press, p. 181-186

Adeleye, D. R. (1973). Origin of ironstones, an example from the Middle Niger valley, Nigeria. Journal of Sedimentary Petrology, 43, 709-727.

Adeleye, D. R. (1974). Sedimentology of the fluvial Bida Sandstones (Cretaceous) Nigeria. Sedimentary Geology, 12, 1-24. http://dx.doi.org/10.1016/0037-0738(74)90013-X

Adeniyi, J. O. (1985). Ground total magnetic intensity in part of Nupe Basin and the adjacent Basement complex, Niger State, Nigeria. Journal of Applied Science, 3, 67-68.

Agyingi, C. M. (1991). Geology of Upper Cretaceous rocks in the eastern Bida Basin, Central Nigeria. Ph.D. dissertation, University of Ibadan, Ibadan, Nigeria, 501p.

Akande, S. O., Ojo, O. J., Erdtmann, B. D., et al. (2005). Paleoenvironments, Organic Petrology and Rock Eval studies on source rock facies of the Campanian to Maastrichtian Patti Formation, southern Bida basin, Nigeria. Journal of African Earth Sciences, 41, 394-406. http://dx.doi.org/10.1016/j.jafrearsci.2005.07.006 
Allen, J. R. L. (1982). Studies in fluvial sedimentation bars, bar complexes and sandstone sheets (low sinuosity braided streams) in the Brownstone Formation (L. Devonian) Welsch borders. Sedimentary Geology, 33, 237-283. http://dx.doi.org/10.1016/0037-0738(83)90076-3

Amajor, L. C. (1984). Sedimentary facies analysis of the Ajali Sandstone (Upper Cretaceous), southern Benue Trough. Journal of Mining and Geology, 21, 171-176.

Amireh, B. S. \& Abed, M. A. (1999). Depositional environments of the Kurnub Group (Early Cretaceous) in northern Jordan. Journal of African Earth Sciences, 29, 449-468. http://dx.doi.org/10.1016/S0899-5362(99)00109-8

Amireh, B. S., Schneider, W., \& Abed, A. M. (1994). Evolving fluvial - transitional - marine deposition through the Cambrian sequence of Jordan. Sedimentary Geology, 89, 65-90. http://dx.doi.org/10.1016/0037-0738(94)90084-1

Blair, T. C. (1987). Tectonic and hydrologic controls on cyclic alluvial fan, fluvial, and lacustrine rift basin sedimentation, Jurassic - Lower most Cretaceous Todos Santos Formation, Chiapas, Mexico. Journal of Sedimentary Petrology, 57, 845-862.

Braide, S. P. (1992a). Syntectonic fluvial sedimentation in the central Bida Basin. Journal of Mining and Geology, 28, 55-64.

Braide, S. P. (1992b). Geological development, origin and energy mineral resources potential of the Lokoja Formation in the southern Bida Basin. Journal of Mining and Geology, 28, 33-44.

Castle, J. W. (2001). Foreland-basin sequence response to collisional tectonism. Geological Society of America Bulletin, 113, 801-812. http://dx.doi.org/10.1130/0016-7606(2001)113<0801:FBSRTC $>2.0 . C O ; 2$

Dott, R. H. Jr. \& Bourgeois, J. (1982). Hummocky stratification: significance of its variable bedding sequences. Bulletin of Geological Society of America, 93, 663-680. http://dx.doi.org/10.1130/0016-7606(1982)93<663:HSSOIV>2.0.CO;2

Elliott, T. E., \& Gardiner, A. R. (1981). Ripple, mega-ripple and sandwave bedforms in the macrotidal Loughor Estuary, South Wales. U.K. Spec. Publs. Int. Ass. Sedim., 5, 51-64.

Idowu, J. O., \& Enu, E. I. (1992). Petroleum geochemistry of some late Cretaceous shale from the Lokoja Sandstone of Middle Niger Basin, Nigeria. Journal of African Earth Sciences, 14, 443-455. http://dx.doi.org/10.1016/0899-5362(92)90047-G

Jan Du Chene, R. E., Adegoke, O. S., Adediran, S. A., et al. (1978). Palynology and foraminifera of the Lokoja Sandstone (Maastrichtian), Bida Basin, Nigeria. Revista Espanola de Micropaleontotologia, 10, 379-393.

Jones, H. A. (1955). The oolitic ironstone of Agbaja Plateau, Kabba Province. Record of Geological Survey Nigeria, (printed in 1958), 20-43.

Kennedy, W. Q. (1965). The influence of basement structure on the evolution of the coastal (Mesozoic and Tertiary) basins. In: Recent Basins around Africa. Proceedings of the Institute of Petroleum Geologists Society, London, pp. 35-47.

King, L. C. (1950). Outline and distribution of Gondwanaland. Geological Magazine, 87, 353-359. http://dx.doi.org/10.1017/S0016756800077311

Klein, G. deV. (1970). Depositional and dispersal dynamics of intertidal sand bars. Journal of Sedimentary Petrology, 40, 973-985.

Kogbe, C. A. (1981). Geological Interpretation of Land sat Imagery of part of Central of central Nigeria. Journal of Mining and Geology, 28, 66-69.

Kogbe, C. A., Ajakaiye, D. E., \& Matheis, G. (1983). Confirmation of rift structure along the middle- Niger Valley, Nigeria. Journal of African Earth Sciences, 1, 127-131. http://dx.doi.org/10.1016/0899-5362(83)90004-0

Ladipo, K. O. (1986). Tidal shelf depositional model for the Ajali Sandstone, Anambra Basin southern Nigeria. Journal of African Earth Sciences, 5, 177-185. http://dx.doi.org/10.1016/0899-5362(86)90008-4

Ladipo, K. O., Akande, S. O. \& Mucke, A. (1994). Genesis of ironstone from middle Niger sedimentary basin evidence from sedimentological, ore microscopic and geochemical studies. Journal of Mining and Geology, 30, 161-168. 
Miall, A. D. (1988). Architectural elements and bounding surfaces in fluvial deposits: anatomy of the Kagenta Formation (Lower Jurasssic), southwest Colorado. Sedimentary Geology, 55, 233-262. http://dx.doi.org/10.1016/0037-0738(88)90133-9

Miall, A. D. (1990). Principles of sedimentary basin analyses. Springer Verlag, New York, 667pp.

Obaje, N. G., Wehner, H., Scheeder, G., et al. (2004). Hydrocarbon prospectivity of Nigeria's inland basins from the viewpoint of organic geochemistry and organic petrology. American Association of Petroleum Geologists Bulletin, 88, 325-353.

Ojo O. J. (2010). Occurrence of some Maastrichtian dinoflagellate cysts from the Upper Cretaceous sediments, in southeastern Bida Basin, Nigeria: Implications for age and paleoenvironments. Global Journal of Geological Sciences, 8, 217-230.

Ojo O. J., Adepoju, S. A., Adewole, T. M., et al. (2011). Sedimentological, geochemical and economic appraisal of Maastrichthian Clays in Bida Basin, central Nigeria. In: Ekosee G-I.E, de Jager, L and Ngole, V.M.(editors) An Innovative Perspective on the Role of Clays and Clay minerals, and Geophagia on Economic Development. Book of Proceedings of the 1st International conference on Clays and Clay Minerals in Africa and 2nd International Conference on Geophagia in Southern Africa, Bloemfontein, South Africa, p.80-90. [Online] Available at: http://www.saweb.co.za/claymineralsafrica

Ojo, O. J \& Akande, S. O. (2009). Sedimentology and depositional environments of the Maastrichtian Patti Formation, southeastern Bida Basin, Nigeria. Cretaceous Research, 30, 1415-1425. http://dx.doi.org/10.1016/j.cretres.2009.08.006

Ojo, O. J. \& Akande, S. O. (2003). Facies Relationships and Depositional Environments of the Upper Cretaceous Lokoja Formation in the Bida Basin, Nigeria. Journal of Mining and Geology, 39, 39-48. http://dx.doi.org/10.4314/jmg.v39i1.18789

Ojo, O. J., \& Akande, S. O. (2006). Sedimentological and palynological studies of the Patti formation, southeastern Bida Basin, Nigeria: Implication for Paleoenvironments and paleogeography. Nigerian Association of Petroleum Explorationists Bulletin, 19, 61-67.

Ojo, S. B. \& Ajakaiye, D. E. (1989). Preliminary interpretation of gravity measurement in the middle Niger Basin area, Nigeria. In; C.A. Kogbe (ed) Geology of Nigeria, $2^{\text {nd }}$ Edition, Elizabeth Publishing Co., Lagos, pp. 347-358

Ojo, S. B. (1984). Middle Niger Basin Revisited, Magnetic constraints on gravity interpretations. Nigerian Mining and Geosciences Society Conference, Nsukka, Nigeria, Abstract vol., p. 52-53.

Ojo. O. J. (1992). Petroleum geology and sedimentology of Patti Formation, Bida Basin, Nigeria. M.Sc. Thesis, University of Ibadan, Ibadan, Nigeria, 149p.

Olaniyan, O., \& Olobaniyi, S. B. (1996). Facies analysis of the Bida Sandstone Formation around Kajita, Nupe Basin, Nigeria. Journal of African Earth Sciences, 23, 253-256. http://dx.doi.org/10.1016/S0899-5362(96)00066-8

Prave, A. R., Duke, W. L., \& Slattery, W. (1996). A depositional model for storm- and tide-influenced prograding siliciclastic shorelines from the Middle Devonian of the central Appalachian foreland basin, USA. Sedimentology, 43, 611-629. http://dx.doi.org/10.1111/j.1365-3091.1996.tb02017.x

Rust, B. R. \& Jones, B. G. (1987). The Hawkesburg Sandstone south of Sydney, Australia: Triassic analogue for the deposit of a large braided river. Journal of Sedimentary Petrology, 57, 222-233.

Selley, R. C. (1985). Ancient Sedimentary Environment, third ed. Cornell University Press, Ithaca, NY, 317p.

Taylor, D. R. \& Lovell, R. W. W. (1991). Recognition of high-frequency sequences in the Kenilworth member of the Blackhawk Formation, Book Cliffs, Utah. In: Van Wangoner, J. C., Nummedal, D., Jones, C. R., et al. (eds.), Sequence stratigraphy applications to Shelf sandstone reservoirs, AAPG Field conference, September 1991, 21-28, pp. 1-8.

Udensi, E. E., Osasuwa, I. B. (2004). Spectra determination of depths to magnetic rocks under the Nupe Basin, Nigeria. Nigeria Association of Petroleum Explorationists Bulletin, 17, 22-37.

Walker, R. G. (1990). Facies modeling and sequence stratigraphy. Journal of Sedimentary Petrology, 60, 777-786.

Whiteman, A. (1982). Nigeria: Its Petroleum Geology, Resources and Potential. Vol. 1 and 2, Graham and Trotman, London, pp349. 


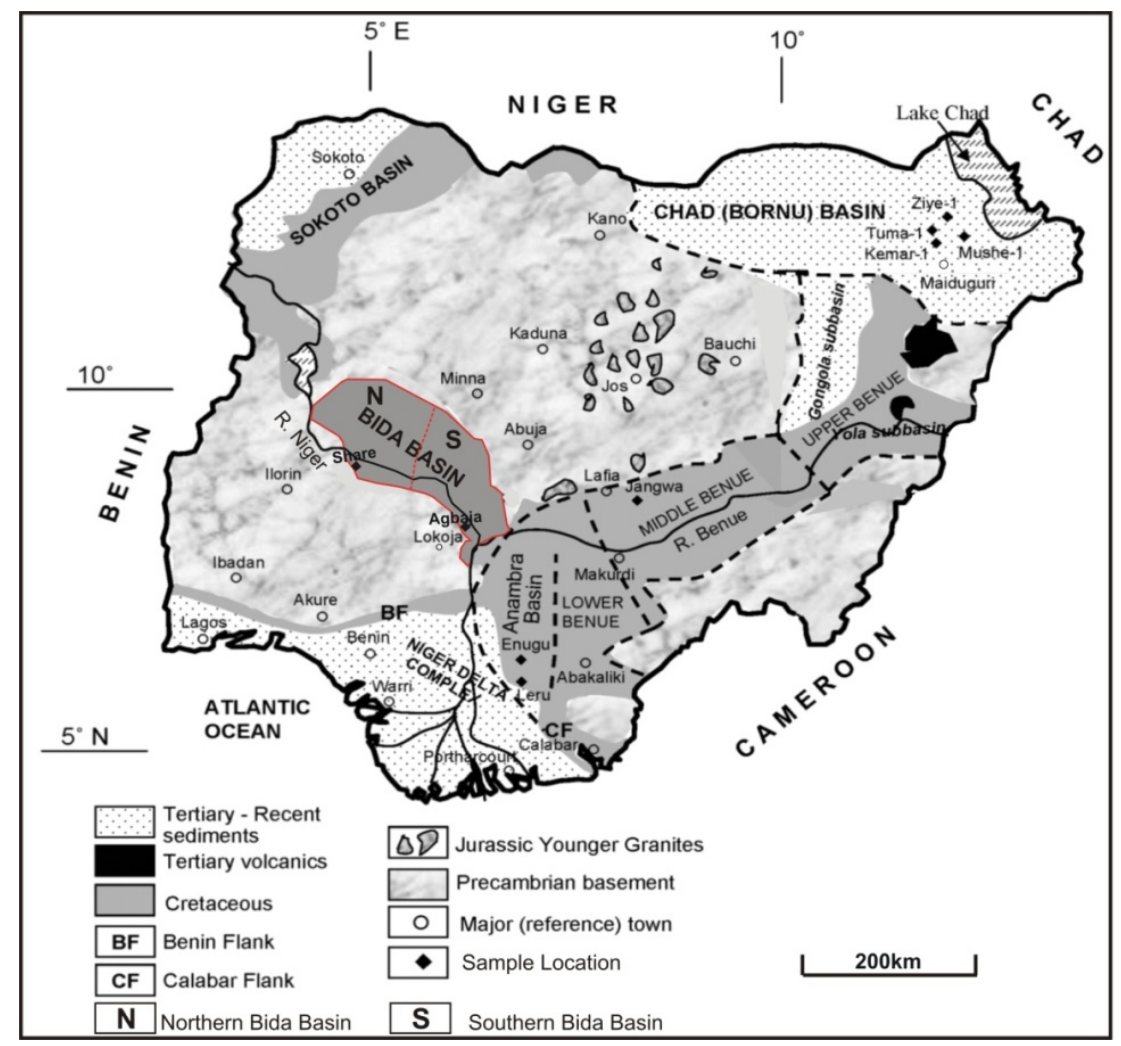

Figure 1. Geological map of Nigeria showing the position of the Bida Basin (Modified after Obaje et al. 2004)

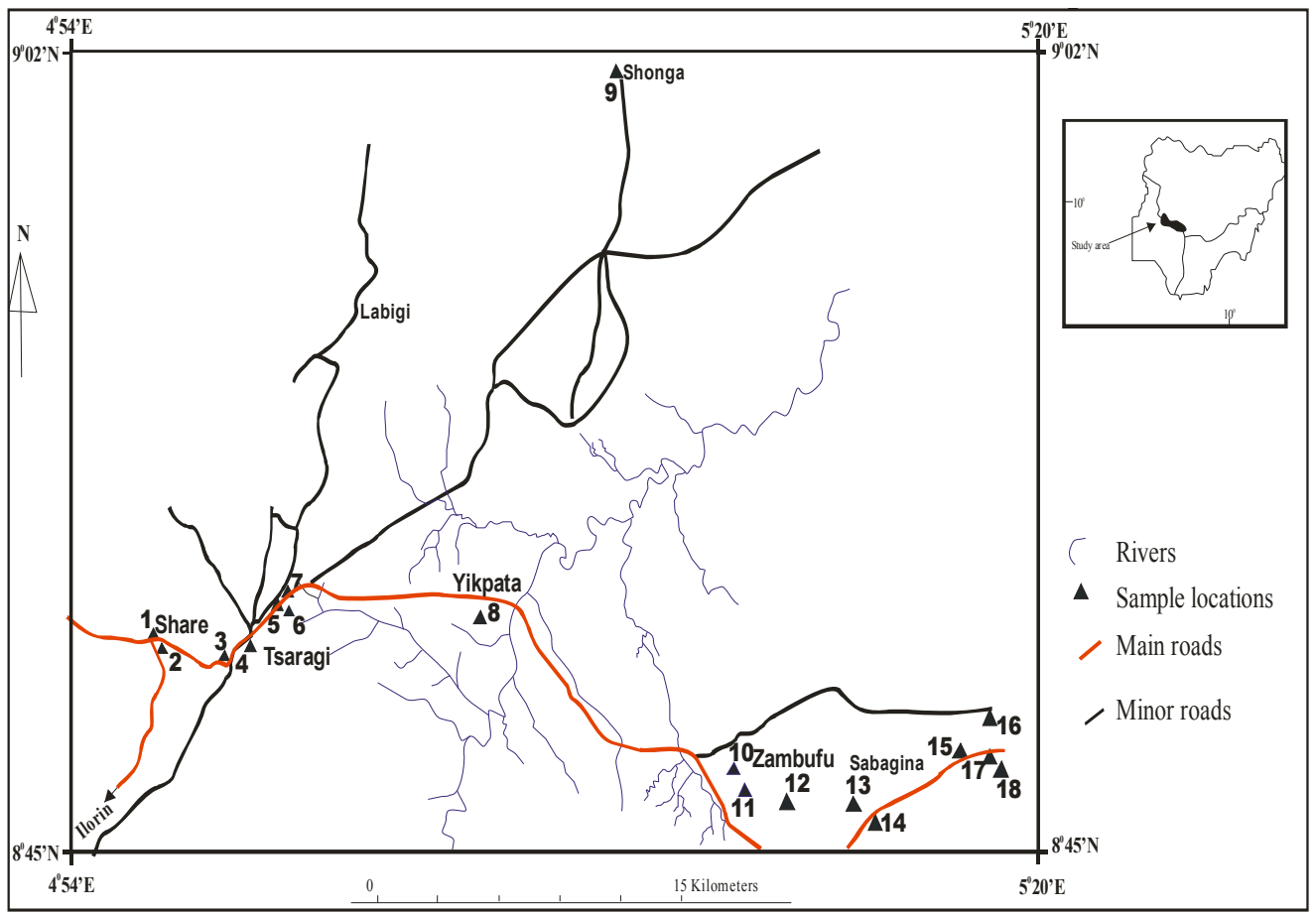

Figure 2. Location map of the investigated outcrops. Inset map of Nigeria showing the Bida Basin 


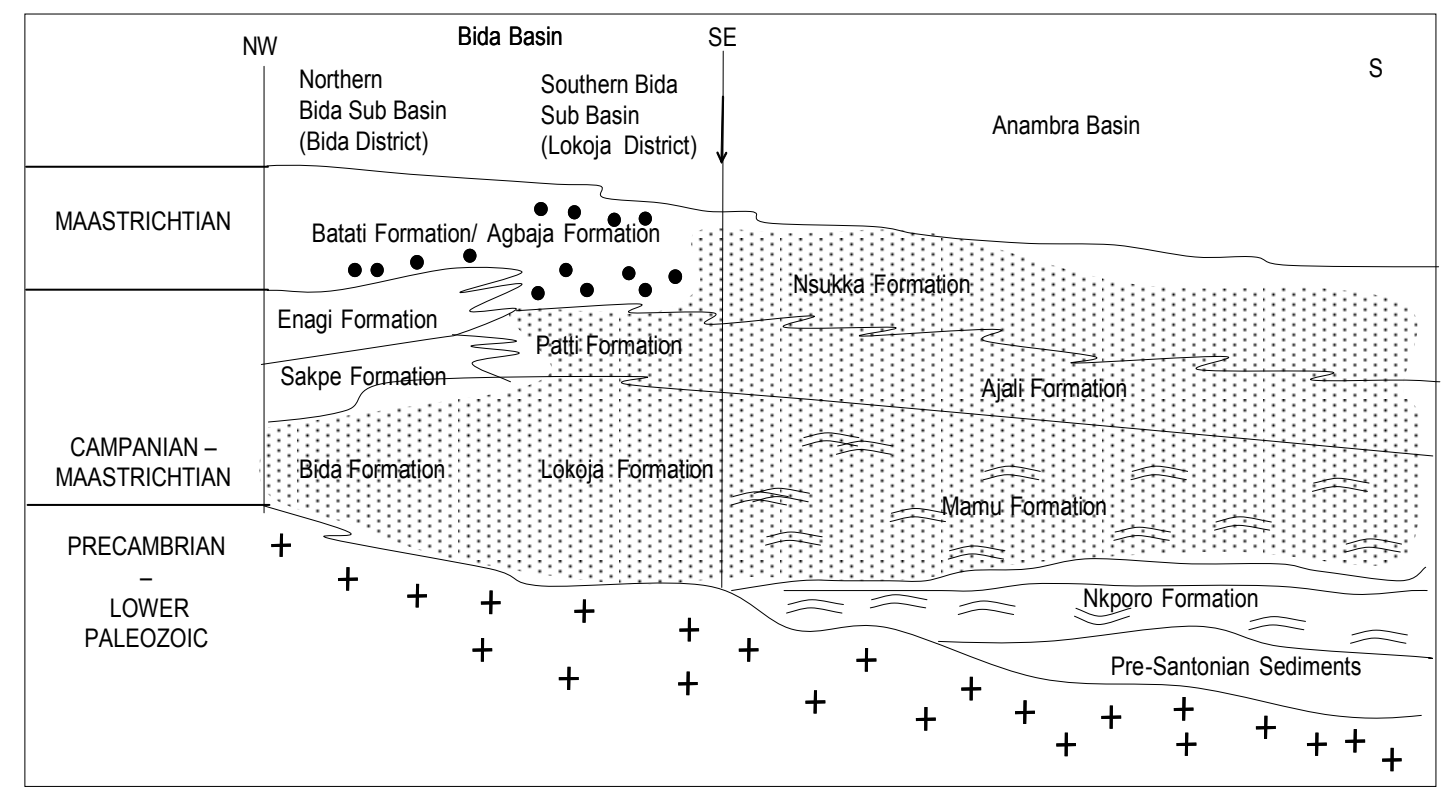

Figure 3. Regional stratigraphic successions in the Bida Basin and their lateral equivalents in the Anambra Basin (Ojo and Akande, 2009). Note, $\mathrm{NW}=$ Northwest, $\mathrm{SE}=$ Southeast, $\mathrm{S}=$ South,$++=$ Crystalline basement rock

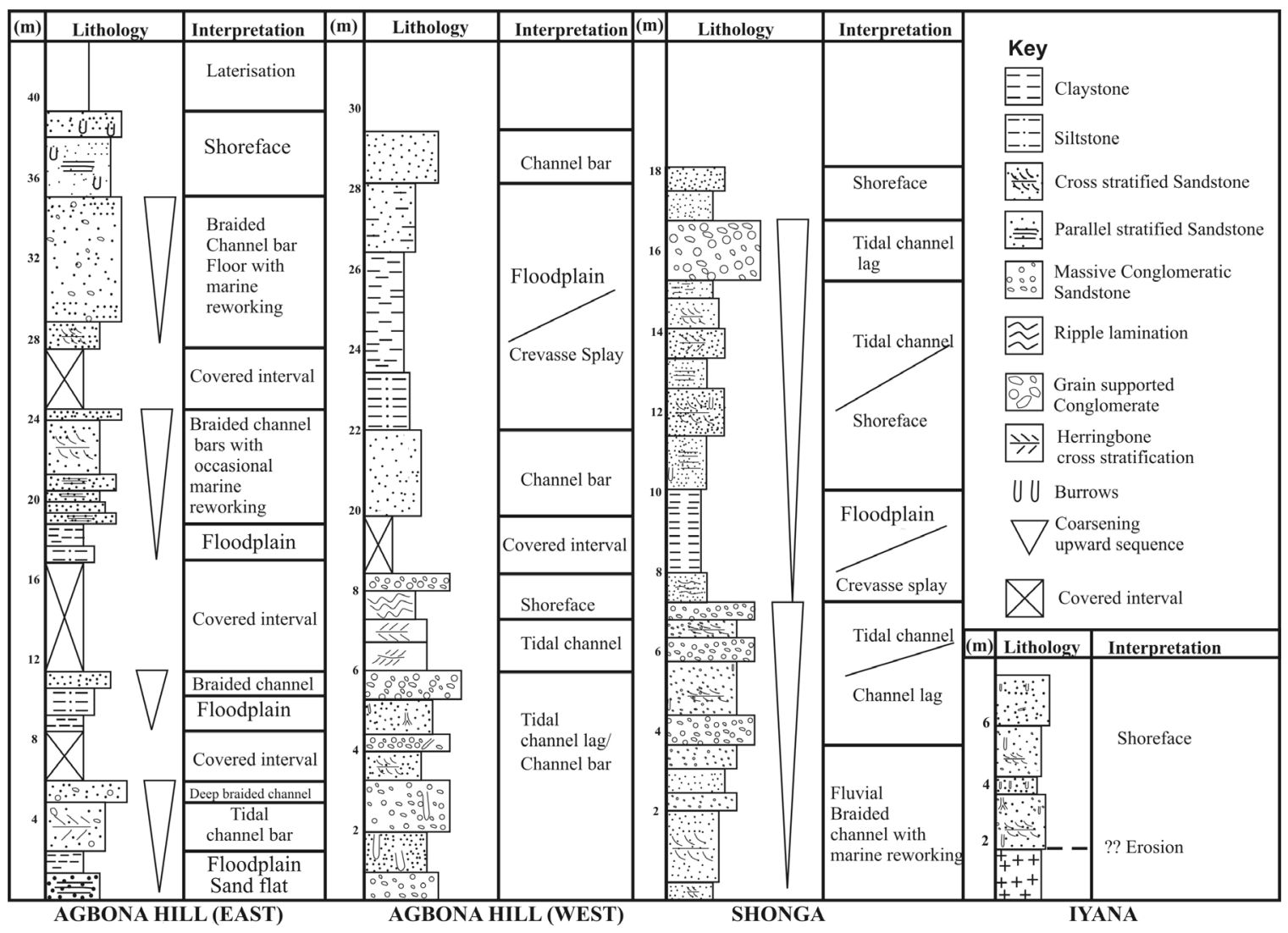

Figure 4. Lithostratigraphic successions of the Enagi Formation exposed at Agbona Hill, Share, Shonga and Iyana, Share 


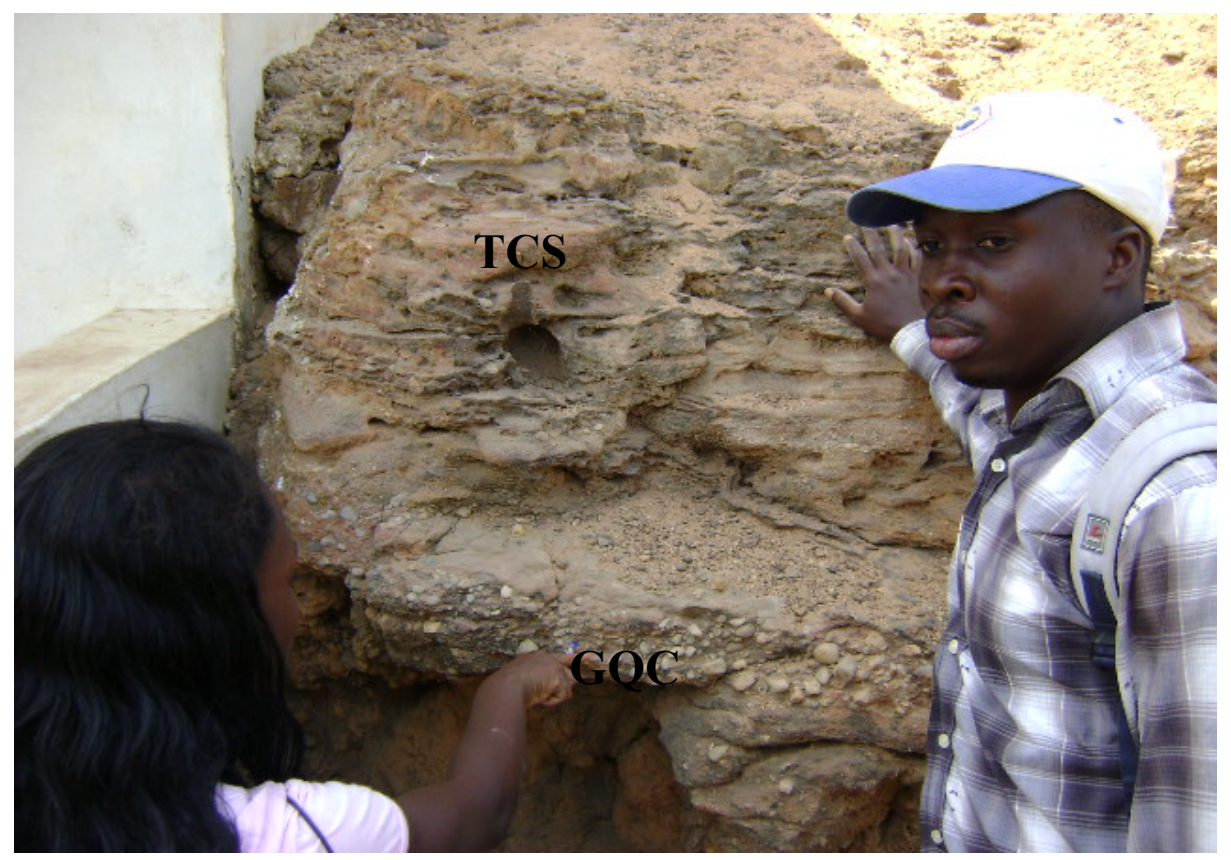

a

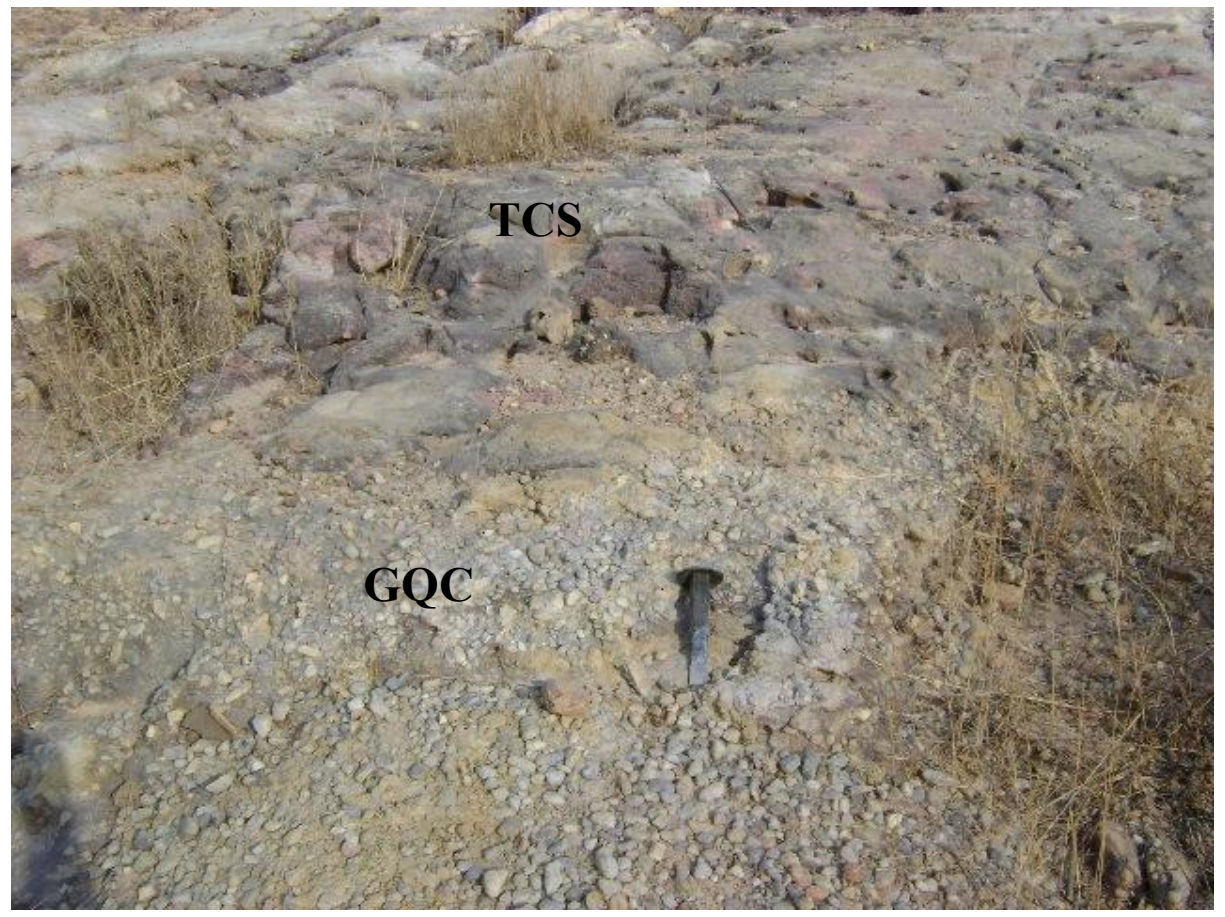

$\mathrm{b}$

Figure 5. (a) Grain supported quartzose conglomerate (GQC) facies characterized by good sorting and well rounded clasts (tidal channel lag) grades into tidal channel sandstone subfacies (TCS) at Agbona Hill, Share and (b) at Shonga 


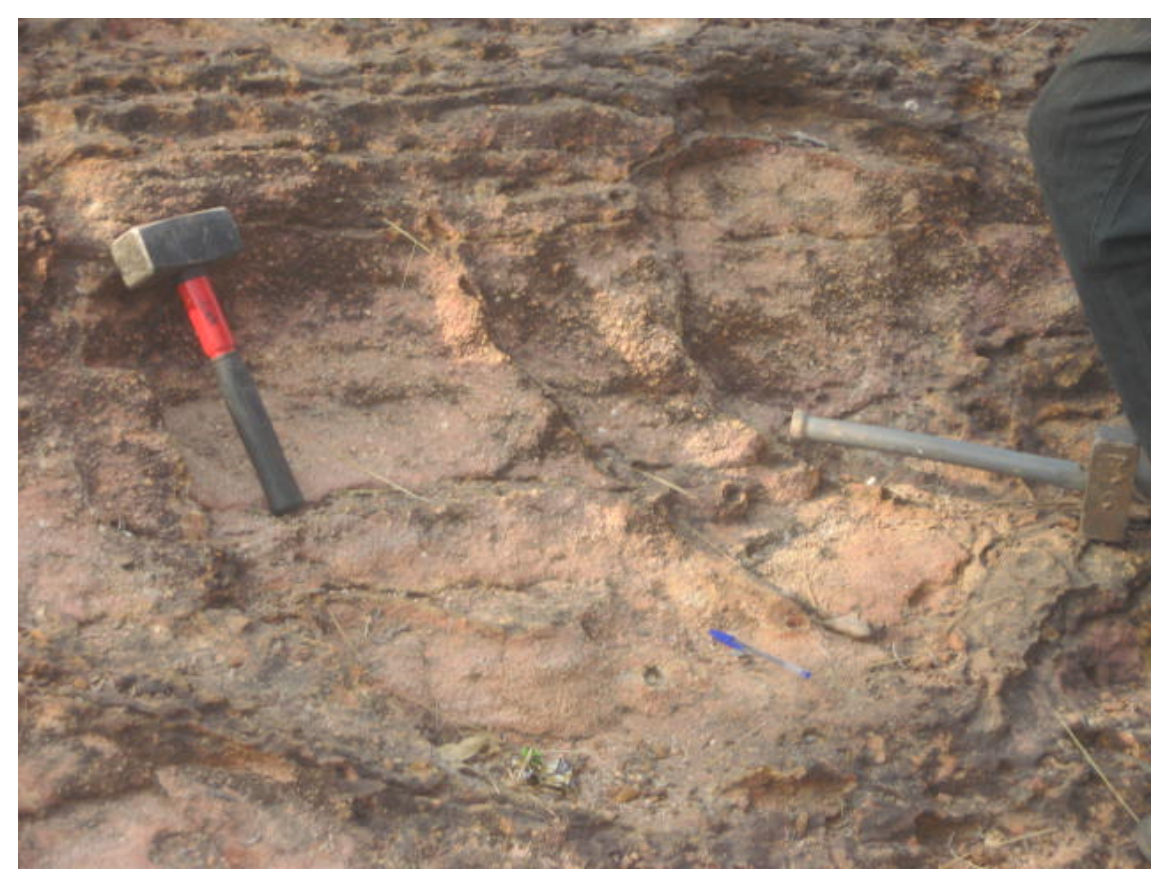

a

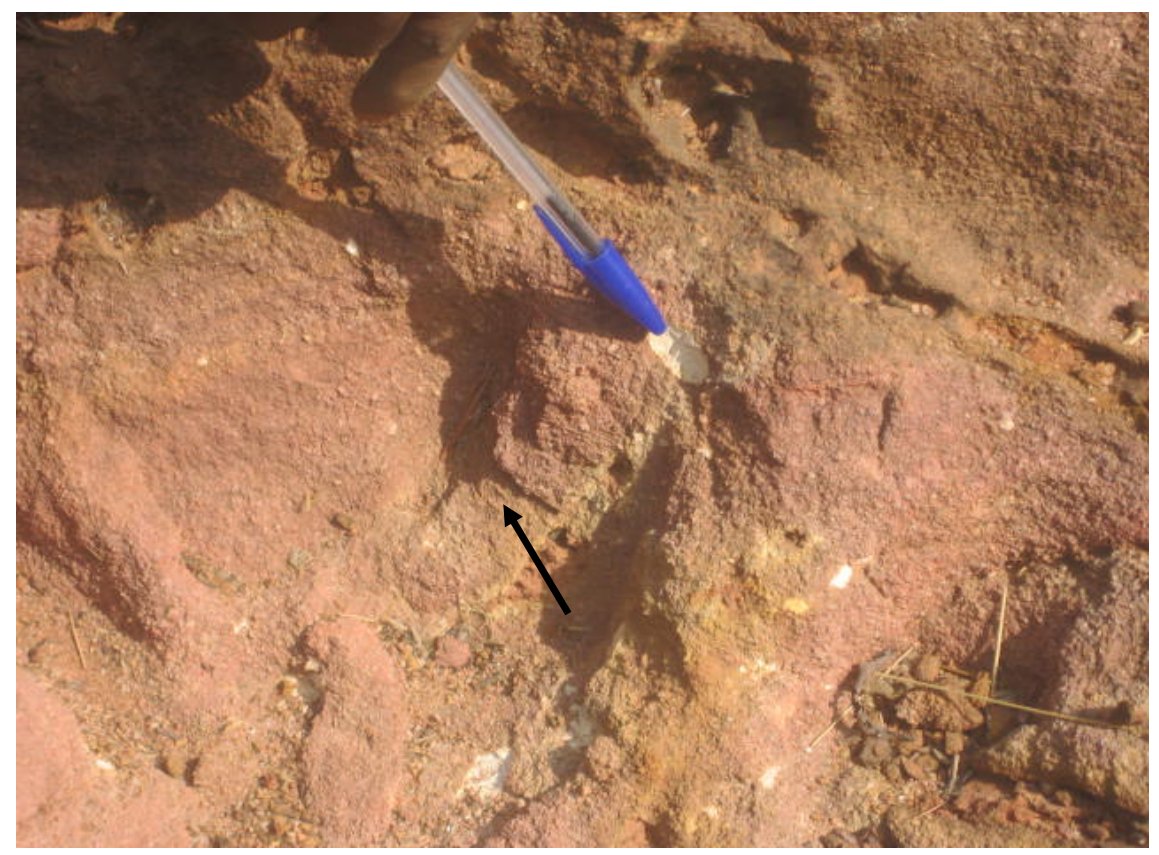

b

Figure 6. (a) Horizontally stratified, mature shoreface subfacies showing coarsening upward trend at Iyana, Share (b) Reworked clay clast and thalassinoides burrow (Arrow) in the massive, shoreface sandstone subfacies at Iyana, Share 


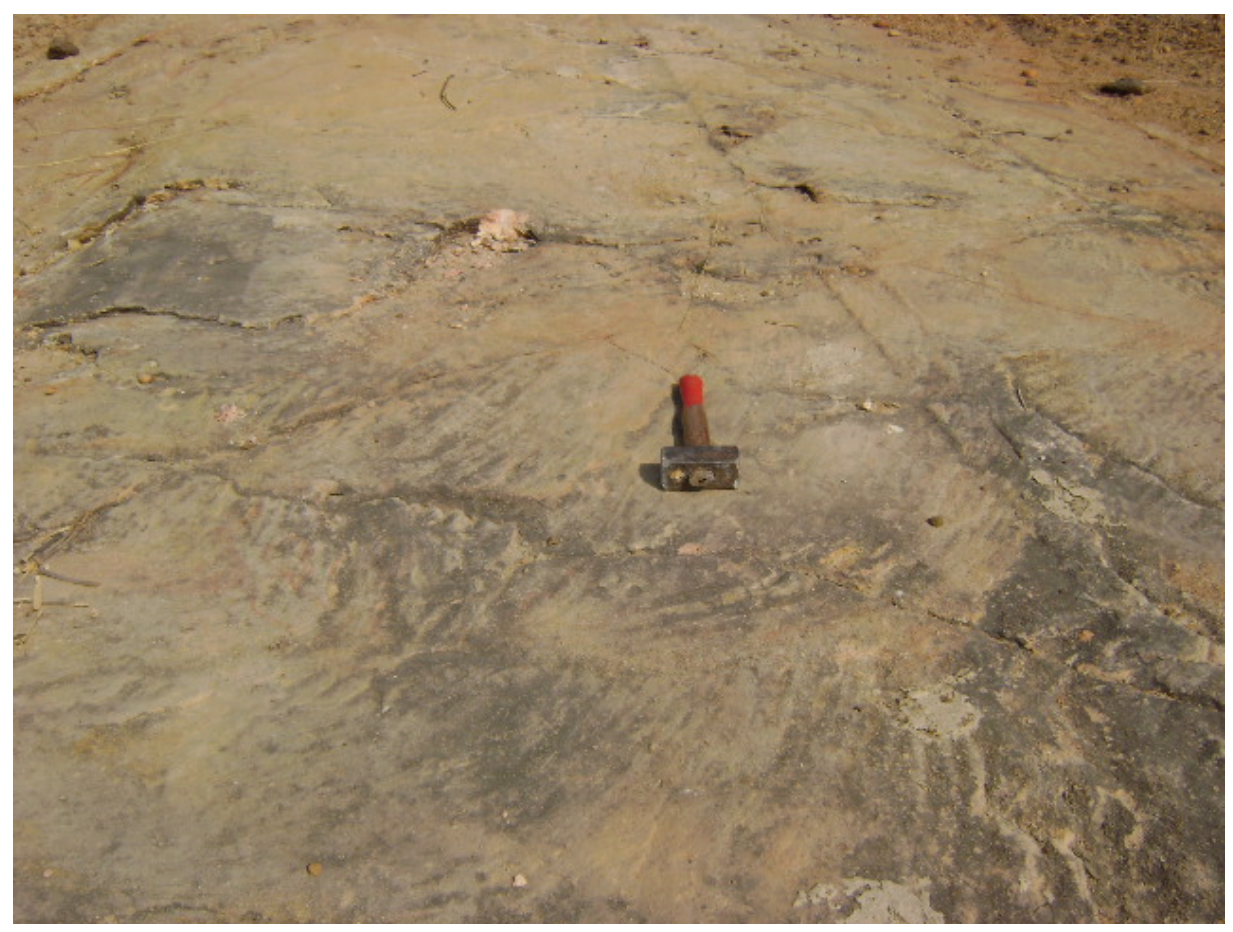

a

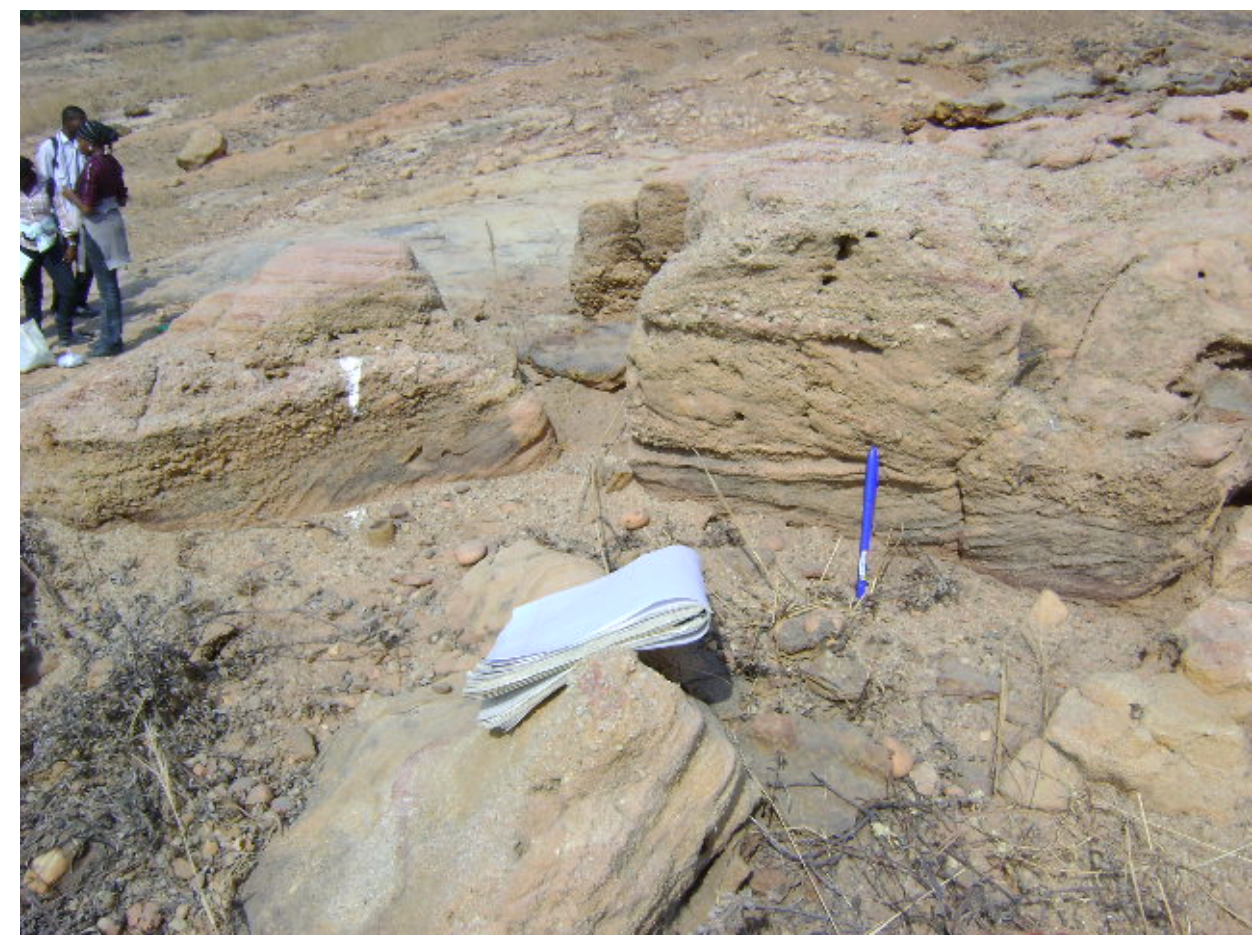

$\mathrm{b}$

Figure 7. (a) Wave ripple laminated, subtidal sandstone facies at Shonga and (b) Herringbone cross bedded sandstone (arrow) subfacies (tidal channel sands) at Shonga 


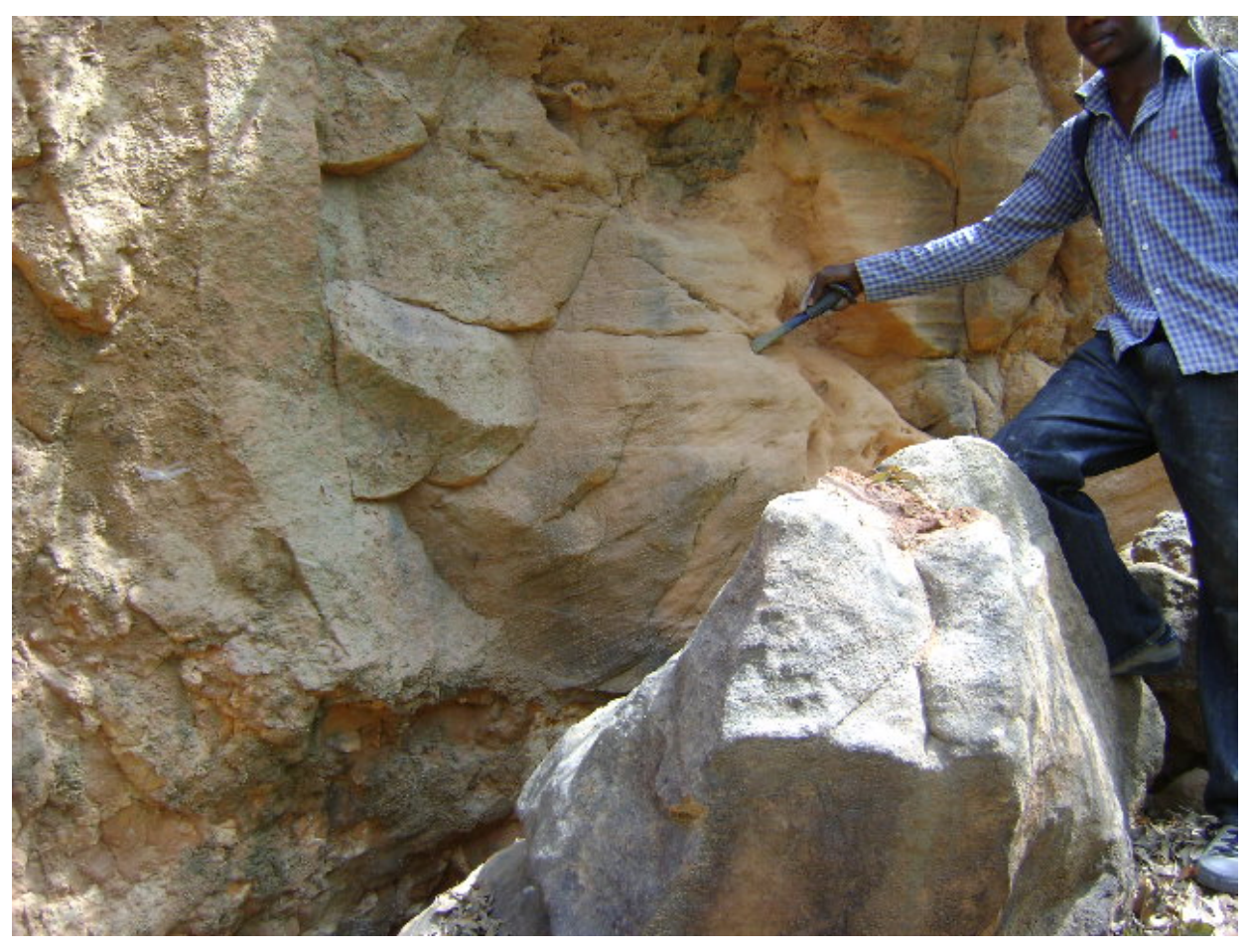

a

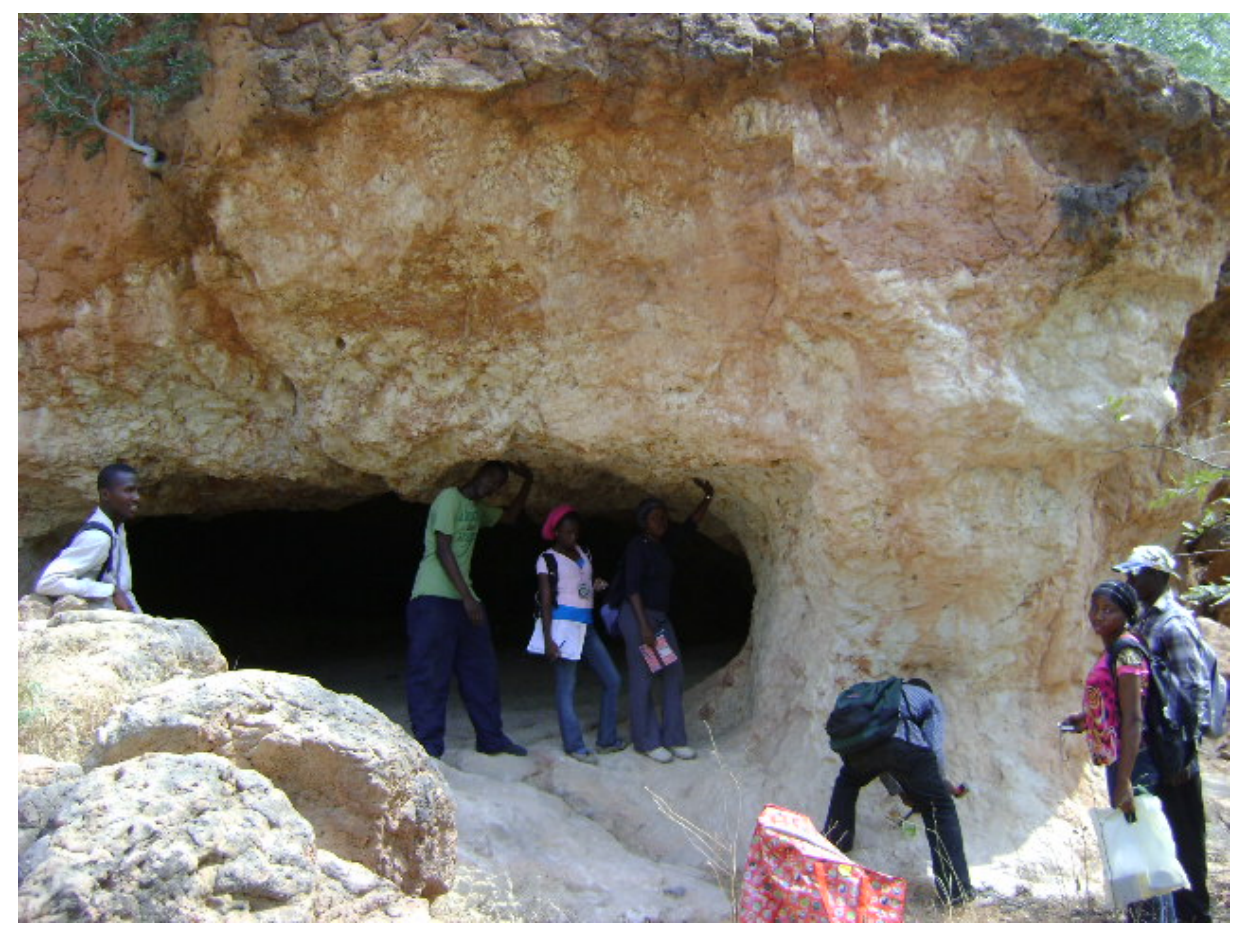

$\mathrm{b}$

Figure 8. (a) Cross bedded sandstone characterized by unidirectional paleocurrent at Agbona ridge Share (b) Floodplain kaolinitic claystone interbedded with mature tidal channel sands at Agbona ridge, Share (artificial cave created by local mining) 